University of Nebraska - Lincoln

DigitalCommons@University of Nebraska - Lincoln

Publications, Agencies and Staff of the U.S.

Department of Commerce

U.S. Department of Commerce

$10-2004$

\title{
Historical Observations of Humpback And Blue Whales in the North Atlantic Ocean: Clues to Migratory Routes and Possibly Additional Feeding Grounds
}

\author{
Randall Reeves \\ Okapi Wildlife Associates \\ Tim D. Smith \\ Northeast Fisheries Science Center \\ Phillip Clapham \\ Northeast Fisheries Science Center \\ Elizabeth Josephson \\ Northeast Fisheries Science Center \\ Gillian Woolmer \\ Wildlife Conservation Society, 2300 Southern Boulevard, Bronx, New York
}

Follow this and additional works at: https://digitalcommons.unl.edu/usdeptcommercepub

Part of the Environmental Sciences Commons

Reeves, Randall; Smith, Tim D.; Clapham, Phillip; Josephson, Elizabeth; and Woolmer, Gillian, "Historical Observations of Humpback And Blue Whales in the North Atlantic Ocean: Clues to Migratory Routes and Possibly Additional Feeding Grounds" (2004). Publications, Agencies and Staff of the U.S. Department of Commerce. 161.

https://digitalcommons.unl.edu/usdeptcommercepub/161

This Article is brought to you for free and open access by the U.S. Department of Commerce at DigitalCommons@University of Nebraska - Lincoln. It has been accepted for inclusion in Publications, Agencies and Staff of the U.S. Department of Commerce by an authorized administrator of DigitalCommons@University of Nebraska - Lincoln. 


\title{
HISTORICAL OBSERVATIONS OF HUMPBACK AND BLUE WHALES IN THE NORTH ATLANTIC OCEAN: CLUES TO MIGRATORY ROUTES AND POSSIBLY ADDITIONAL FEEDING GROUNDS
}

\author{
RANDALl R. REeves \\ Okapi Wildlife Associates, 27 Chandler Lane, \\ Hudson, Quebec JOP 1Ho, Canada \\ E-mail: rrreeves@total.net \\ Tim D. SMITH \\ Elizabeth A. Josephon \\ Phillip J. Clapham \\ Northeast Fisheries Science Center, 166 Water Street, \\ Woods Hole, Massachusetts 02543, U.S.A. \\ GILLIAN WOOLMER \\ Wildlife Conservation Society, \\ 2300 Southern Boulevard, \\ Bronx, New York 10460, U.S.A.
}

\begin{abstract}
The seasonal distributions of humpback and blue whales (Megaptera novaeangliae and Balaenoptera musculus, respectively) in the North Atlantic Ocean are not fully understood. Although humpbacks have been studied intensively in nearshore or coastal feeding and breeding areas, their migratory movements between these areas have been largely inferred. Blue whales have only been studied intensively along the north shore of the Gulf of St. Lawrence, and their seasonal occurrence and movements elsewhere in the North Atlantic are poorly known. We investigated the historical seasonal distributions of these two species using sighting and catch data extracted from American 18th and 19th century whaling logbooks. These data suggest that humpback whales migrated seasonally from low-latitude calving/ breeding grounds over a protracted period, and that some of them traveled far offshore rather than following coastal toutes. Also, at least some humpbacks apparently fed early in the summer west of the Mid-Atlantic Ridge, well south of their known present-day feeding grounds. In assessing the present status of the North Atlantic humpback population, it will be important to determine whether such offshore feeding does in fact occur. Blue whales were present across the southern half of the North Atlantic during the autumn and winter months, and farther north in spring and summer, but we had too few data points to support inferences about these whales' migratory timing and routes.
\end{abstract}

Key words: humpback whale, Megaptera novaeangliae, blue whale, Balaenoptera musculus, migration, North Atlantic, Mid-Atlantic Ridge. 
Of all of the world's whales, the humpback whale (Megaptera novaeangliae) in the North Atlantic Ocean is one of the best studied. Not only is there a long history of exploitation, providing evidence of past seasonal distribution and relative abundance, but extensive research has also been conducted on living humpback whales during the last quarter-century. The migratory behavior of humpback whales is reasonably well understood, primarily in relation to the endpoints of their migrations, i.e., the summer feeding grounds in mid- to high latitudes and the tropical winter breeding grounds (e.g., Katona and Beard 1991, Clapham et al. 1993, Stevick et al. 1999, Jann et al. 2003). Matching of individuals photographed on the breeding grounds with individuals photographed on the feeding grounds has been the principal tool for achieving such understanding. While acknowledging that migration routes between the summer and winter aggregation areas are unknown, Katona and Beard (1991) inferred that the southbound trajectories to the West Indies, at least, are "well offshore," considering the lack of winter sightings along the east coast of North America and at Bermuda. Satellite-linked radio-tracking of several individual humpback whales in the central North Pacific has provided at least a glimpse of the timing, route, and specd of the early stages of their northward migration from Hawaii (Mate et al. 1998), but no similar satellite-tagging data are available on humpback whales in other parts of their cosmopolitan range. A novel method of studying the migratory behavior of humpback (and other) whales has been the use of sound recordings from bottom-mounted hydrophones to infer seasonal trends in the animals' occurrence at different sites in the North Arlantic (Charif $t$ al. 2001) and North Pacific (Watkins et al. 2000). For example, Charif et al. (2001) suggested a southbound migration of humpbacks to the west of the British Isles, but they were unable to detect a corresponding norrhbound migration after the breeding season.

Blue whales (Balaenoptera musculus) are much more difficult to study in view of their comparatively low abundance and tendency to remain in deep water. However, long-term studies of individually photo-identified animals have provided some insights on frequency of occurrence in the St. Lawrence River and Gulf of St. Lawrence (Sears $e t$ al. 1990). One of the whales photo-identified in the northwestern Gulf in 1984 and 1985 was observed off West Greenland in 1988 and 1989, then back in the Gulf in 1991, 1992, and 1994 (Sears and Larsen 2002), indicating the potential for fairly long-distance separation of feeding grounds between years. Also, passive acoustic tracking of individuals has been interpreted to suggest that blue whales move over great distances, perhaps covering much of the North Atlantic basin (Clark 1994). Acoustic data from blue whales in the North Pacific have been analyzed extensively and used to identify key oceanic features that help determine their distribution (Moore et al. 2002).

Recent studies have employed data from 18th and 19th century whaling logbooks to establish where and when concentrations of humpback whales occurred and, to some extent, to infer their historical migration routes (Reeves et al. 2001, 2002). To our knowledge, no previous attempt has been made to analyze blue whale data from these old logbooks.

The present study uses unpublished data on sightings, as well as catches and attempted catches (collectively called "encounters") extracted from American whaling logbooks, in combination with data from the Townsend (1935) charts, to analyze the monthly distribution of humpback and blue whales in the North Atlantic Ocean. Findings are then used to infer those species' historical seasonal distribution and migratory behavior. 


\section{METHODS}

\section{Logbook Data Extraction}

American whaling logbooks were examined for information on humpback whales on their North Atlantic breeding grounds (Reeves et al. 2001, 2002; Reeves and Smith 2002; Smith and Reeves 2003), right whales (Eubalaena glatialis) throughout their North Atlantic range (Reeves and Mitchell 1986, Reeves 2001), and bowhead whales (Balaena mysticetus) on their Hudson Bay feeding grounds (Reeves and Cosens 2003). In the course of this work, reports of encounters with blue whales and with humpback whales outside their breeding grounds were noted in a non-systematic fashion. These blue and humpback whale records were assembled in a database that included date, number observed, geographic location, vessel name, and sailing and return years. Locations were given in the logbooks either as degrees and minutes of latitude and longitude, or by reference to a geographical landmark (e.g., a coastal town, an island, or a whaling ground). In some instances, it was necessary to interpolate the position from information recorded on days preceding and following the one in question.

Whaleship positions on days of encounters with humpback and blue whales were plotted as single points on monthly charts of the North Atlantic Ocean using a Robinson projection centered at $40^{\circ} \mathrm{W}$ longitude.

\section{Use of Townsend's Sperm Whale Data as a Proxy for Effort}

In neither Townsend's study (1935) nor the present one was it possible to estimate catch or encounter rates because the data extracted from the logbooks did not include information on whaling activity on days when whales were not sighted or caught. Without a means to calculate encounter rates for humpback and blue whales on a daily basis, such as sightings per day (cf. Bannister et al. 1981, for sperm whales, Physeter macrocephalus, in the North Pacific), it is difficult to evaluate the representativeness of the spatial and seasonal distributions of the encounter data. Whitehead and Jaquer (1996) explicitly advised caution in inferring seasonal changes in whale abundance, even with effort-weighted catch data, because of possible seasonal variability in the efficiency of whaless (for example, due to variations in wind speed). We used Townsend's sperm whale catch positions as a crude proxy for whaling effort, and further, we based our conclusions only on presence and not on absence of whale encounters.

\section{Replotting of Data from Townsend (1935)}

We extracted the names and approximate locations of the North Atlantic sperm whaling grounds shown on Townsend's Charts $A$ and $B$, and plotted them on a shaded bathymetry map of the North Atlantic in Robinson projection (centered at $40^{\circ} \mathrm{W}$ longitude) (Fig. 1).

The positions of whaling vessels when whales were caught in the North Atlantic, as shown on the Townsend (1935) charts, were digitized. ${ }^{1}$ The charts were scanned at

\footnotetext{
I This work was carried out by the Wildlife Conservation Society (formerly New York Zoological Society, publisher of the original Townsend charts). Color scans of the original Townsend charts and the digitized whale catch locations are available from the Wildlife Conservation Society, http:/ www.wcs.org/townsend_charts.
} 


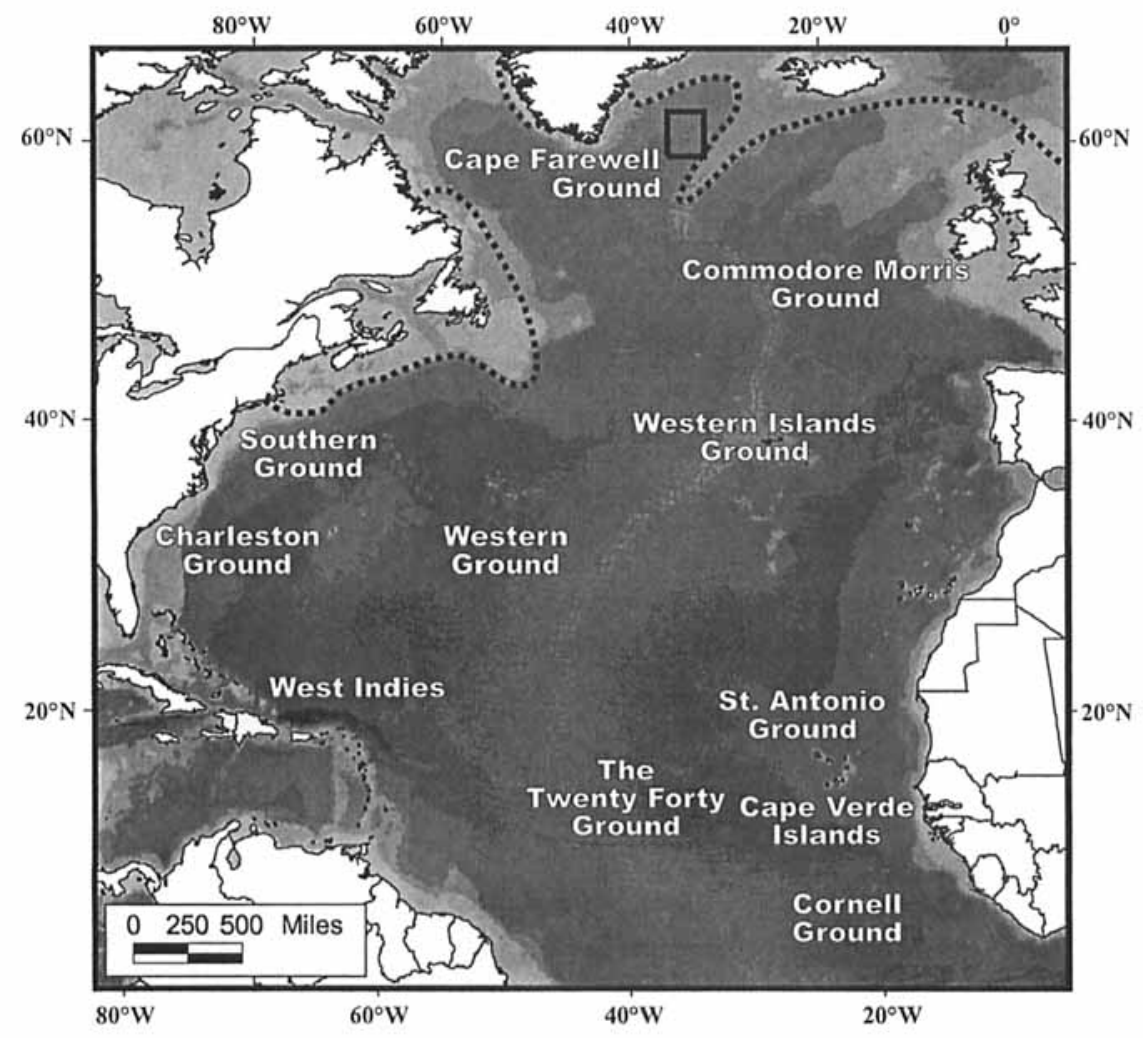

Figure 1. North Atlantic Ocean with depth gradients, whaling grounds, and known summer distribution of humpback whales. The depth gradients are from the ETOPO2 data set produced by the National Geographic Data Center at NOAA (www.ngdc.noaa.gov/mgg/ fliers $/ 01 \mathrm{mgg} 04 . \mathrm{html})$. The names and locations of the sperm whaling grounds are from Townsend (1935), and the Cape Farewell Ground (for right whales) is from logbook information. The West Indies and Cape Verde Islands were also humpback whaling grounds that were visited by American whalers during winter months, as well as to catch sperm whales during various seasons. The more southern aspects of the known present-day summer feeding grounds of humpback whales are within and north of the areas delineated by the dotted lines.

200 dots per inch and geo-referenced in Mercator coordinates using geographic information system software (Arcview 3.2). The decision to use a Mercator projection, in the absence of any indication of map projection on the charts themselves, was based on consultations with experts in old maps and naval charts. The latitude and longitude of each distinguishable whaling vessel location on the Townsend charts were determined, along with the month denoted by the associated symbol (i.e., color coding and open or closed dot). The legends of the four Townsend charts indicate that a total of 53,320 catches were represented; 34,153 positions were successfully digitized. The difference is likely due to multiple whale catches at any given location, the omission of points by Townsend's cartographer for lack of space due to the density of vessel locations, the misinterpretation of multiple, closely overlaid points of the same or similar colors as one point, and, of course, human error. Nonetheless, the digitized 


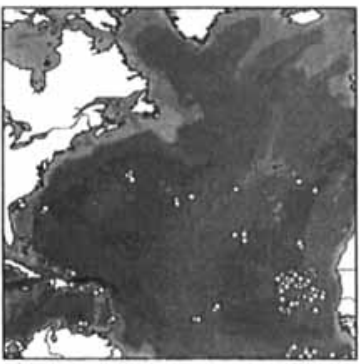

a) January

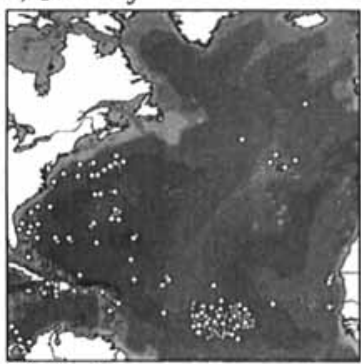

d) April

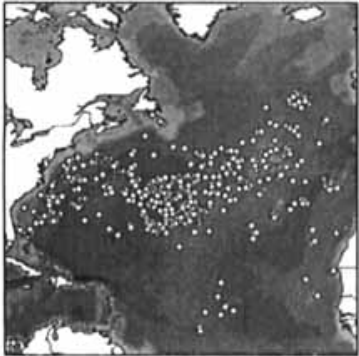

g) July

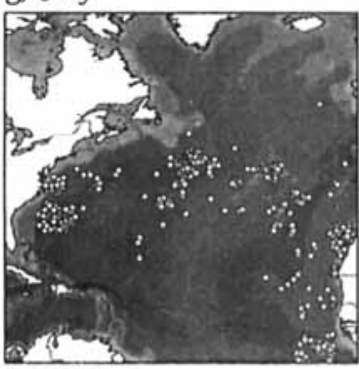

j) October

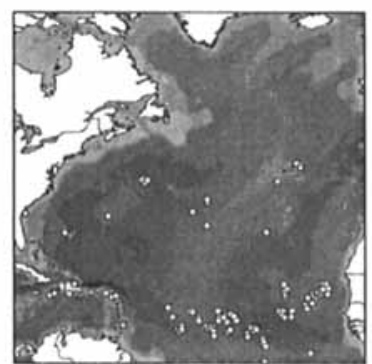

b) February

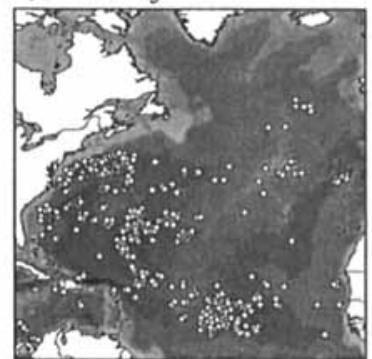

e) May

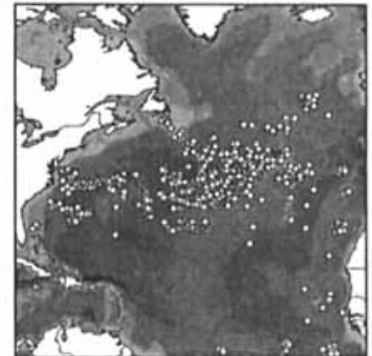

h) August

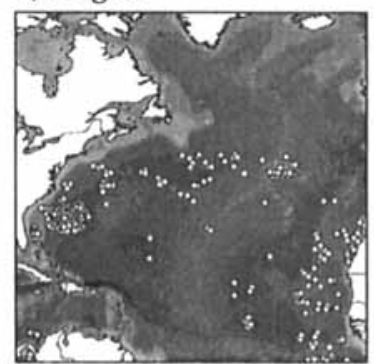

k) November

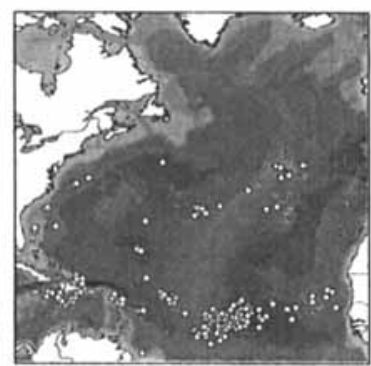

c) March

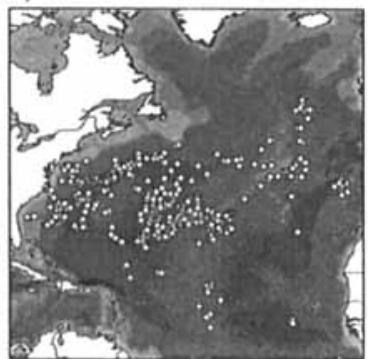

f) June

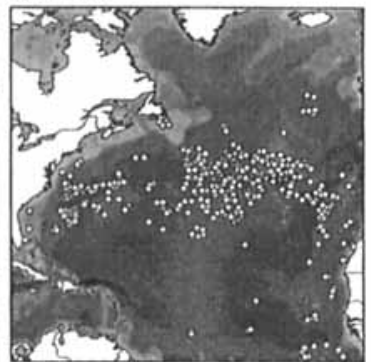

i) September

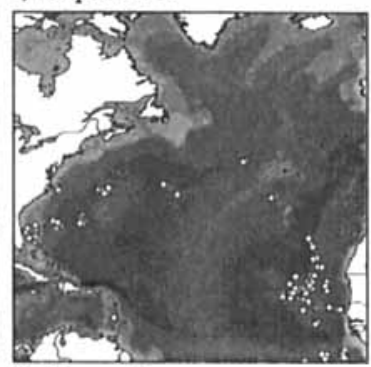

1) December

Figure 2. Monthly locations of American whaleships (white dots) on days when sperm whales were taken in the North Atlantic, as digitized from Townsend (1935).

points, when replotted, produce essentially the same visual pattern as shown on the original charts. For each month, we replotted from Townsend's charts, using the same Robinson projection, the digitized positions of vessels on days when sperm whales were caught (Fig. 2). 
Humpback Whale Feeding Grounds

Although "feeding aggregation" areas are frequently mentioned in synoptic analyses (e.g., Katona and Beard 1990, 1991, Palsbøll et al. 1997, Smith et al. 1999, IWC 2002), even their approximate boundaries have not been mapped. In general, the humpback whale's summer feeding distribution encompasses coastal margins from the Gulf of Maine northward and eastward, including the Gulf of St. Lawrence, waters off Newfoundland, Labrador, and West and East Greenland, and much of the Barents and Norwegian seas. In the Barents Sea, humpbacks regularly occur as far east as $40^{\circ} \mathrm{E}$ and as far north as $80^{\circ} \mathrm{N}$. We asked colleagues in the United States, Canada, Greenland, Iceland, and Norway to indicate on a chart the summer range of humpback whales in their waters. The sketches and other information that they provided were consolidated on a single chart, and the implied southern boundary was digitized and overlaid on Figure 1.

\section{RESULTS}

\section{Distribution of Logbook Records and Whaling Effort}

The logbook records consisted of 210 encounters with humpback whales drawn from 92 logbooks (Fig. 3) and 75 encounters with blue whales drawn from 32 logbooks (Fig. 4). These points show pronounced shifts by month, with a generally northward movement in the spring and summer for both species. The 149 points for humpback whales from Townsend's chart, most of them on or near the two breeding grounds, reflected catches rather than encounters. A small cluster of "humpback" catch positions on the original Townsend chart implied a humpback whale wintering area (December to March) adjacent to the northwestern coast of Africa. However, after inspecting the same records that Townsend used, and compiling much additional information from the area, Reeves and Mitchell (1990) concluded that Townsend had erred in recording as humpback whales the unspecified "whales" hunted on the Cintra Bay Ground when in fact they were right whales. We have therefore excluded these records from our depiction of humpback whale distribution (Fig. 3).

The seasonal and spatial distribution of sperm whale catches shows the pattern of American open-ocean whaling in the North Atlantic during the 19th century (Fig. 2). Effort during the autumn was concentrated in the east on the Cornell and St. Antonio grounds and south of the Canary Islands and in the west on the Charleston Ground. The winter months were spent mainly south of the Tropic of Cancer on the St. Antonio, Twelve Forty, and West Indies grounds. The Twelve Forty Ground remained popular through the spring, but by May, June, and July effort had shifted northward, and the largest catches were made on the Charleston, Southern, Western, and Western Islands grounds throughout the summer months. The Commodore Morris Ground southwest of Ireland and the Grand Banks off Newfoundland were whaled principally from July to September. There were relatively few catches in the southern areas from June through September.

By comparing the sperm whale catch distribution (Fig. 2) to the distribution of encounters with humpback and blue whales (Fig. 3, 4), it is possible to obtain a rough indication of how closely the frequency of encounters with non-target species was correlated to whaling effort. For example, there is a large mid-ocean area bounded on the north by the Azores (Western Islands Ground), on the west by the 


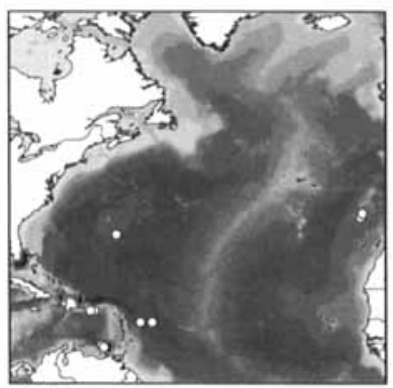

a) January

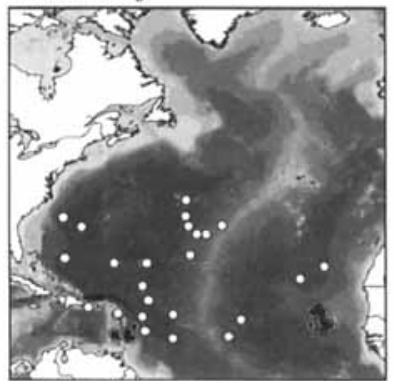

d) April

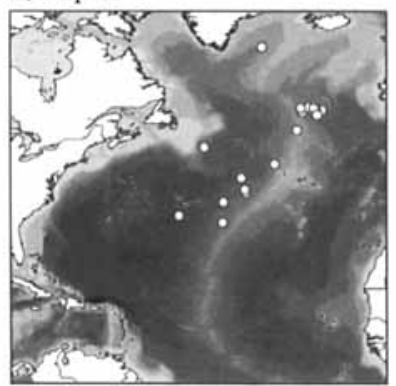

g) July

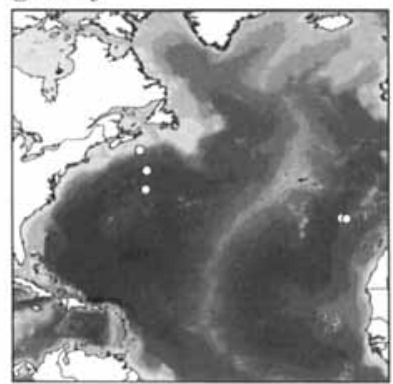

j) October

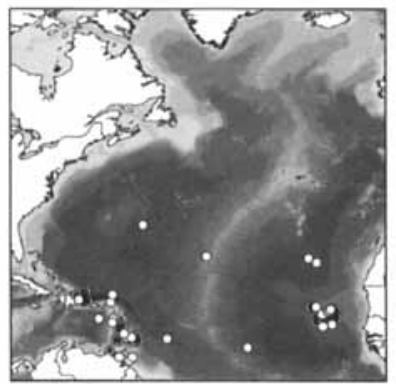

b) February

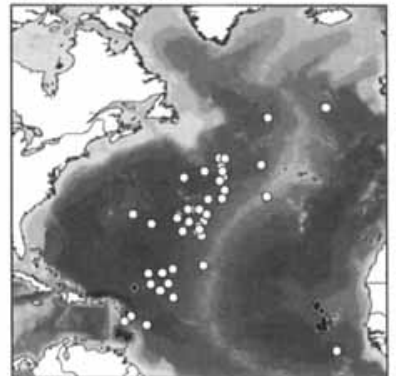

e) May

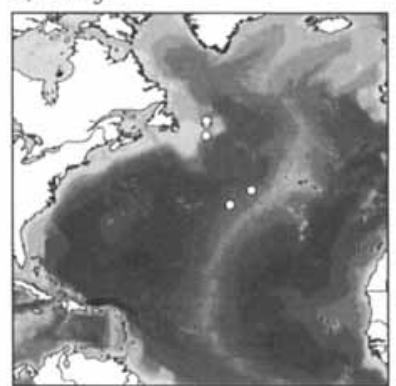

h) August

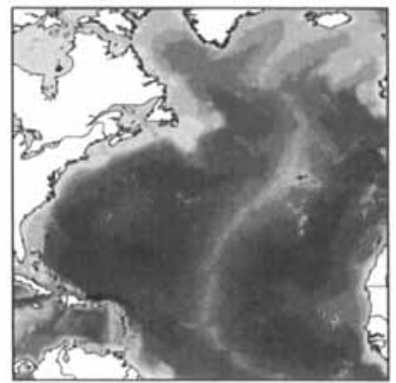

k) November

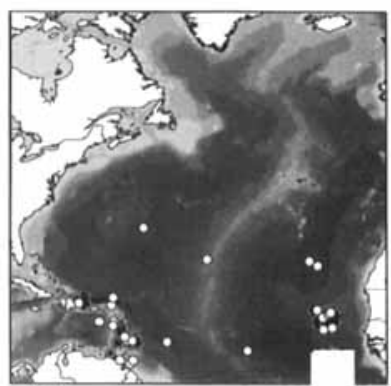

c) March

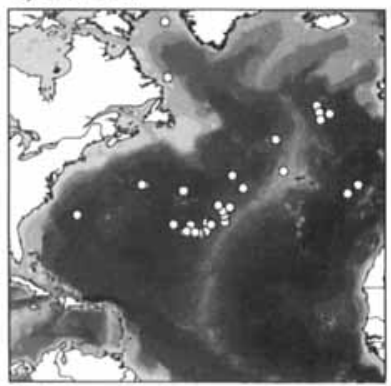

f) June

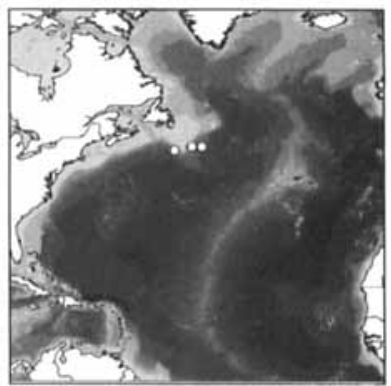

i) September

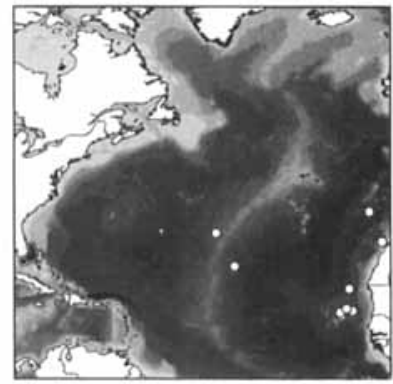

1) December

Figure 3. Monthly locations of American whaleships on days when humpback whales (white dots) were encountered, as reported in whalers' logbooks, along with the digitized Townsend (1935) records of humpback whales (white dots with dark centers). 

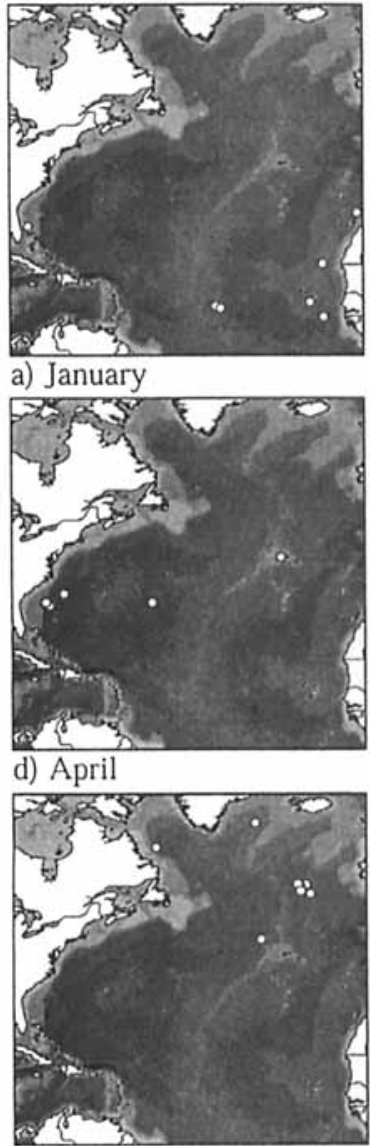

g) July

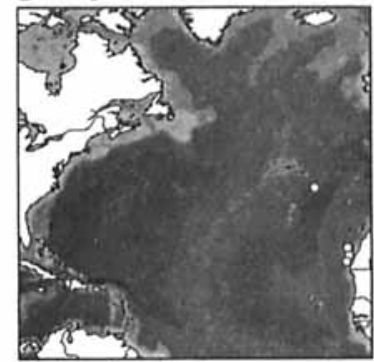

j) October
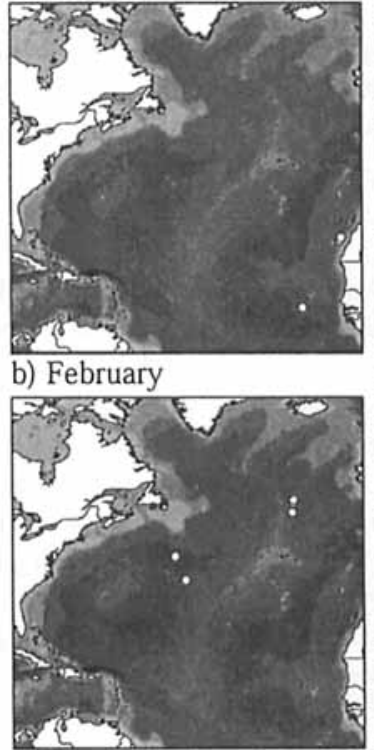

e) May

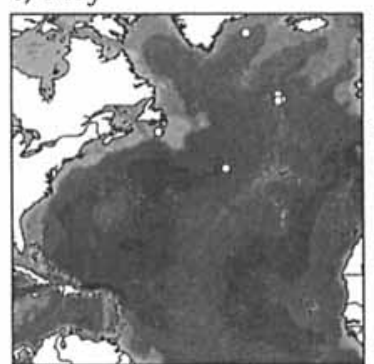

h) August

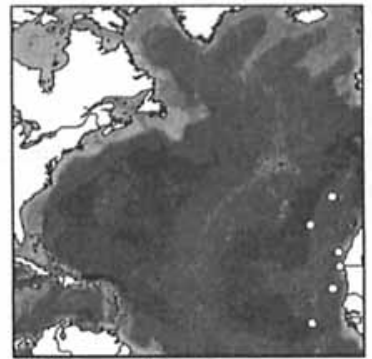

k) November

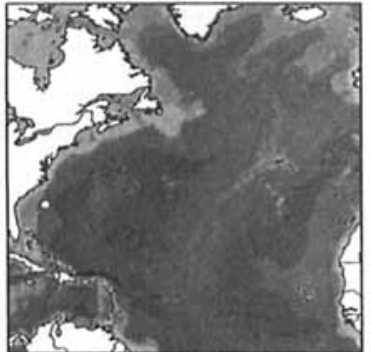

c) March

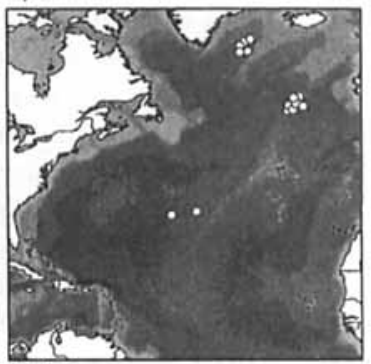

f) June

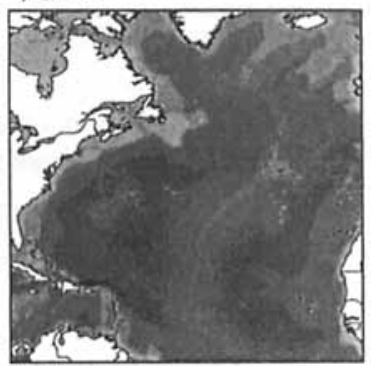

i) September

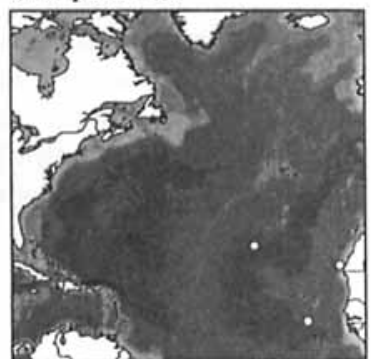

1) December

Figure 4. Monthly locations of American whaleships on days when blue whales (white dots) were encountered, as reported in whalers' logbooks.

Western Ground, on the south by the Twelve Forty and St. Antonio grounds, and on the east by the Canary Islands (see Fig. 1,2), where one would expect few or no records of these other species, as very few sperm whales were taken there at any time of the year (Fig. 2). Similarly, one would expect observations on the Commodore 
Morris Ground only during the summer (June-September) and on the Western and Western Islands grounds primarily during the summer and autumn (JuneNovember), as these were the periods when most of the sperm whale catches were made in those areas (Fig. 2).

\section{Humpback Whales}

The seasonal and spatial distribution of humpback whale encounters (Fig. 3) clearly shows the more southerly occurrence in the winter and spring (January-May) on or near the two calving/breeding grounds (mainly from the Townsend records), followed by a northerly dispersion during the late spring (late April-June; mainly from the logbook records of encounters). Although there is a suggestion of a gap between western and eastern migratory "streams" of humpback whales, this could be an artifact of low whaling effort in the large mid-ocean area mentioned earlier (see Fig. 2). A notable feature is the relatively high number of encounters with humpback whales in the north-central North Atlantic, generally along the western side of the North Atlantic Ridge during the late spring and summer months, with a few encounters also near the southern margins of the known present-day feeding grounds. There is a cluster of encounters on the Commodore Morris Ground, mainly in June and July.

Sperm whale catches generally were not recorded by Townsend in the northern regions where summer aggregations of humpback whales are known to occur today (Fig.1), and we interpret this to mean that there was little whaling effort there ( $c f$. Fig. 2). The few humpback encounters off Newfoundland, Labrador, and Greenland (Fig. 3) came from logbooks of voyages in pursuit of right or bowhead whales in high latitudes.

\section{Blue Whales}

The encounters plotted for blue whales show a broad longitudinal distribution in tropical and warm temperate latitudes during the winter months, with a narrower and more northerly distribution in summer (Fig. 4). Regarding the latter, the cluster of records on the Cape Farewell Ground was clearly associated with the search for right whales (see Reeves and Mitchell 1986, Reeves 2001), while the cluster on the Commodore Morris Ground was associated with the summer whaling there for sperm whales (Fig. 2).

\section{Discussion}

For most of the historical records of humpback and blue whales presented here, it can be assumed that the whalers were searching primarily for sperm whales when they saw these other species, essentially in passing. Indeed, most of the incidental or opportunistic observations were on the sperm whale grounds where search effort was most intense and prolonged. An important exception is the concentration of blue whales on the Cape Farewell Ground where right whales were the target species. The absence or rarity of records of humpback and blue whales in areas and at times with large numbers of sperm whale dots can be considered a true reflection of those species' low densities in such areas.

In interpreting our results, it is important to bear in mind that the data on blue 
whales and on humpback whales outside the calving/breeding grounds were extracted unsystematically and not always rigorously. Therefore, it is likely that these data are a subset, albeit perhaps a large subset, of the total information available on these species in the examined logbooks. Furthermore, there are numerous additional Atlantic voyage logbooks in public collections that were not examined and that undoubtedly contain additional relevant data on humpback and blue whales ( $c f$. Sherman et al. 1986, Lund 2001).

The humpback whale encounters recorded in the present study for spring (AprilMay) and summer (June-August) complement the catch data plotted by Townsend (1935) primarily for winter (January-March). Together, these data strongly imply a northward migration toward the feeding grounds (Fig. 3). A striking feature of this movement is its dispersion both longitudinally and latitudinally. Rather than giving a clear signal of a tightly regimented, strictly synchronous migration, the data suggest a broad-band, diffuse migration that occurs over the course of several months. There is also a suggestion that some animals occur along the western margins of the North Atlantic Ridge during at least a portion of the feeding season-June through August. This raises the possibility that, at least historically, some humpback whales fed well south of the known present-day feeding grounds. Such mid-latitude feeding areas would have been distant from the relatively coastal grounds where humpbacks have been studied in recent years. It must be recognized, however, that judging by the large number of sperm whale catches on the Western Ground and Western Islands Ground during the summer months (Fig. 2), search effort in those regions in the summer was very high, and therefore the actual density of humpback whales there may have been fairly low.

The Commodore Morris Ground, centered at about $50^{\circ} \mathrm{N}, 22^{\circ} \mathrm{W}$, is of particular interest as it was the northernmost sperm whaling ground in the North Atlantic (summer only; see Townsend's Chart A), and a relatively large number of the humpback observations were on this ground in June and July. On the western side of the Atlantic, the observations of humpback whales along the margins of the Grand Banks during August and September are consistent with the species' wellknown present-day distribution. The limited number of these records is easily explained by the relative lack of whaling effort in the northwestern part of the North Atlantic basin (Fig. 2).

This study represents the first attempt to use data from historical whaling logbooks to elucidate the spatial and seasonal distribution of blue whales. Most of the whaling for blue whales in the North Atlantic was from shore stations in highlatitude areas such as Norway, Iceland, and Newfoundland (Jonsgård 1977, Tønnessen and Johnsen 1982), so the offshore mid- and low-latitude records shown in Figure 4 are of particular interest. The reference by Jonsgård (1966) to published 20th century records of blue whales between the Cape Verde Islands and the African coast at approximately $18^{\circ} \mathrm{N}, 18^{\circ} \mathrm{W}$ in March and November is consistent with the observations in this region reported by American 19th century whalers (Fig. 4).

Finally, it is important to emphasize that the distributions of humpback and blue whales as depicted here, based solely upon data from logbooks of the American openboat whale fishery, are far from comprehensive. Their total historical distributions are much more extensive than indicated in our charts. For example, data from modern shore whaling stations during the late 19th and early 20 th centuries indicate that there were large numbers of humpback whales and blue whales off Norway and Iceland (Risting 1922). Humpbacks were even seen migrating westward along the Finnmark coast of northern Norway during the winter months of February, March, 
and April, and the adult females were carrying large fetuses, suggesting a possible calving/breeding area in addition to those currently known in the Cape Verdes and West Indies (Ingebrigtsen 1929). At the same period, a modern shore station on the south coast of Newfoundland took blue whales regularly during the winter and spring months from late December through early May (Dickinson and Sanger 1990). The known present-day concentration areas for blue whales in the Gulf of St. Lawrence (Sears et al. 1990) and around Iceland (Sigurjónsson and Gunnlaugsson 1990) were seldom visited by American open-boat whalers in pursuit of sperm whales (Fig. 1,2), so the lack of records for those areas in the present study is not surprising.

\section{ACKNOWLEDGMENTS}

Financial support for this work was provided by the Alfred E. Sloan Foundation and the National Oceanic and Atmospheric Administration, from both its National Marine Fisheries Service and its Office of Ocean Exploration. We gratefully acknowledge the contributions of the staff, students, and interns of the Landscape Ecology and Geographic Analysis Program at the Wildlife Conservation Society, Eric W. Sanderson, and especially Trisha Devoe, Denise Su, Prosanta Chakrabarty, Aditya Agrawal, and Diane Greer, who digitized the Townsend whaling charts. We are also grateful to John Bannister for his suggestion that we use Townsend's plots of sperm whale catches as a proxy for whaling effort and to two anonymous reviewers for helpful comments.

\section{Literature Cited}

Bannister, J. L., S. TAYLOR AND H. SUTHERLAND. 1981. Logbook records of 19th century American sperm whaling: A report on the 12 month project, 1978-79. Report of the International Whaling Commission 31:821-833.

Charif, R. A., P. J. Clapham and C. W. Clark. 2001. Acoustic detections of singing humpback whales in deep waters off the British Isles. Marine Mammal Science 17:751-768.

Clapham, P. J., D. K. Mattila And P. J. Palsbøli. 1993. High latitude area composition of humpback whale competitive groups in Samana Bay-further evidence for panmixis in the North Atlantic population. Canadian Journal of Zoology 71:1065-1066.

Clark, C. W. 1994. Blue deep voices: insights from the Navy's Whales '93 program. Whalewatcher 28(1):6-11.

Dickinson, A., AND C. SAnger. 1990. Modern shore-based whaling in Newfoundland and Labrador: Expansion and consolidation, 1898-1902. International Journal of Maritime History 2:83-116.

InGeBRIGTSEN, A. 1929. Whales caught in the North Atlantic and other seas. Rapports et Procès-verbaux des réunions, Conseil Permanent International pour l'Exploration de la Mer LVI:1-26.

IWC. 2002. Report of the Sub-committee on the Comprehensive Assessment of North Atlantic Humpback Whales. Journal of Cetacean Research and Management (Supplement) 4:230-260.

Jann, B., J. Allien, M. Carrillo, S. Hanquet, S. K. Katona, A. R. Martin, R. R. Reeves, R. Seton, P. T. Stevick AND F. W. Wenzel. 2003. Migration of a humpback whale (Megaptera novaeangliae) between the Cape Verde Islands and Iceland. Journal of Cetacean Research and Management 5:125-129.

JonsGÅRD, $\AA$. 1966. The distribution of Balaenopteridae in the North Atlantic Ocean. Pages 114-124 in K. S. Norris, ed. Whales, dolphins, and porpoises. University of California Press, Berkeley, CA.

JONSGÅRD, $\AA$. 1977. Tábles showing the catch of small whales (including minke whales) 
caught by Norwegians in the period 1938-75, and large whales caught in different North Atlantic waters in the period 1868-1975. Report of the International Whaling Commission 27:413-425.

Katona, S. K., And J. A. Beard. 1990. Population size, migrations and feeding aggregations of the humpback whale (Megaptera novaeangliae) in the western North Atlantic Ocean. Report of the International Whaling Commission (Special Issue 12):295-305.

Katona, S. K., AND J. A. BeARD. 1991. Humpback whales (Megaptera novaeangliae) in the western North Atlantic Ocean. Memoirs of the Queensland Museum 30:307-321.

LunD, J. N. 2001. Whaling masters and whaling voyages sailing from American ports: A compilation of sources. New Bedford Whaling Museum, New Bedford, MA; Kendall Whaling Museum, Sharon, MA; and Ten Pound Island Book Co., Gloucester, MA.

Mate, B. R., R. GISINER AND J. MOBLEY. 1998. Local and migratory movements of Hawaiian humpback whales tracked by satellite telemetry. Canadian Journal of Zoology 76:863868.

Moore, S. E., W. A. Watkins, M. A. Daher, J. R. Davies and M. E. Dahlheim. 2002. Blue whale habitat associations in the northwest Pacific: Analysis of remotely-sensed data using a Geographical Information System. Oceanography 14:20-25.

Palsbøll, P. J., J. Ailen, M. Bérubé, P. J. Clapham, T. P. Feddersen, P. S. Hammond, R. R. Hudson, H. Jørgensen, S. Katona, A. H. Larsen, F. Larsen, J. Lien, D. K. Mattila, J. Sigurjónsson, R. Sears, T. Smith, R. Spooner, P. Stevick and N. Øien. 1997. Genetic tagging of humpback whales. Nature 388:767-769.

REEVES, R. R. 2001. Overview of catch history, historic abundance and distribution of right whales in the western North Atlantic and in Cintra Bay, West Africa. Journal of Cetacean Research and Management (Special Issue 2):187-192.

Refeves, R. R., AND E. Mitchell. 1986. American pelagic whaling for right whales in the North Atlantic. Report of the International Whaling Commission (Special Issue 10):221-254.

Refyes, R. R., AND E. MrtChelt. 1990. Right whales, not humpbacks, taken in Cintra Bay. American Neptune 50:119-126.

Reeves, R. R., AND T. D. SMIth. 2002. Historical catches of humpback whales in the North Atlantic Ocean: An overview of sources. Journal of Cetacean Research and Management 4:219-234.

REEVES, R. R., AND S. E. CosENs. 2003. Historical population characteristics of bowhead whales (Balaena mysticetus) in Hudson Bay. Arctic 56:283-292.

Reeves, R. R., S. L. Swartz, S. E. Wetmore and P. J. Clapham. 2001. Historical occurrence and distribution of humpback whales in the eastern and southern Caribbean Sea, based on data from American whaling logbooks. Journal of Cetacean Research and Management 3:117-129.

Reeves, R. R., P. J. Clapham And S. E. Wetmore. 2002. Humpback whale (Megaptera novaeangliae) occurrence near the Cape Verde Islands, based on American 19th century whaling records. Journal of Cetacean Research and Management 4:235-253.

RistinG, S. 1922. Av hvalfangstens historie. Kristiania, Norges.

SEARS, R., AND F. LARSEN. 2002. Long range movements of a blue whale (Balaenoptera musculus) between the Gulf of St. Lawrence and West Greenland. Marine Mammal Science 18:281-285.

Sears, R., J. M. Williamson, F. W. Wenzel, M. Bérubé, D. Gendron and P. W. Jones. 1990. Photographic identification of the blue whale (Balaenoptera musculus) in the Gulf of St. Lawrence, Canada. Report of the International Whaling Commission (Special Issue 12):335-342.

Sherman, S. C., J. M. Downey, V. M. Adams and H. Pasternack. 1986. Whaling logbooks and journals 1613-1927: An inventory of manuscript records in public collections. Garland Publ., New York and London.

Sigurjónsson, J., and TH. Gunnlaugsson. 1990. Recent trends in abundance of blue (Balaenoptera musculus) and humpback whales (Megaptera novaeangliae) off west and 
souchwest Iceland, with a note on occurrence of other cetacean species. Report of the International Whaling Commission 40:537-551.

SMITH, T. D., AND R. R. ReEves. 2003. Estimating American $19^{\text {th }}$ century catches of humpback whales in the West Indies and Cape Verde Islands. Caribbean Journal of Science 39:286-297.

Smith, T. D., J. Allen, P. J. Clapham, P. S. Hammond, S. Katona, F. Larsfin, J. Lifin, D. Mattila, P. J. Paisboll, J. Sigurjónsson, P. T. Stevick and N. Oien. 1999. An oceanbasin-wide mark-recapture study of the North Atlantic humpback whale (Megatera novaeangliae). Marine Mammal Science 15:1-32.

Stevick, P. T., N. ØIEN AND D. K. MatTila. 1999. Migratory destinations of humpback whales from Norwegian and adjacent waters: Evidence for stock identity. Journal of Cetacean Research and Management 1:147-152.

Tonnessen, J. N., ANd A. O. JoHnsen. 1982. The history of modern whaling. University of California Press, Los Angeles, CA.

Townsend, C. H. 1935. The distribution of certain whales as shown by logbook records of American whaleships. Zoologica 19:1-50+4 charts.

Watkins, W. A., M. A. Daher, G. M. Reppucci, J. E. George, D. L. Martin, N. A. Dimarzio And D. P. Gannon. 2000. Seasonality and distribution of whale calls in the North Pacific. Oceanography 13:62--67.

WhITEHEAD, H., AND N. JAQUET. 1996. Are the charts of Maury and Townsend good indicators of sperm whale distribution and seasonality? Report of the International Whaling Commission 46:643-657.

Received: 15 October 2003 Accepted: 12 March 2004 